\title{
Peluang Imbuhan Pakan Herbal-Probiotik Komersial "Promix®" sebagai Pengganti Antibiotic Growth Promoter (AGP) pada Ayam Pedaging yang Diberi Vaksin ND
}

\section{The Opportunities of Feed Additif of Commercial Herbal-Probiotic "Promix ${ }^{\circledR}$ "Feed as a Substitute for Antibiotic Growth Promoter (AGP) in Broilers Given ND Vaccines}

\author{
Agnesia Endang Tri Hastuti Wahyuni ${ }^{1 *}$, Vinsa Cantya Prakasita ${ }^{2}$, Thomas Emanuel Manggotu Nahak ${ }^{2}$, Agustina \\ Viktoria Tae $^{2}$, Jeffi Chandra Ajiguna ${ }^{2}$, Sruti Listra Adrenalin ${ }^{2}$, Lynda Nugrahaning Imanjati ${ }^{2}$, Ima Fuaziah ${ }^{2}$ \\ ${ }^{1}$ Departemen Mikrobiologi, Fakultas Kedokteran Hewan, Universitas Gadjah Mada, \\ Jl. Fauna 2 Karangmalang, Depok, Sleman, Yogyakarta 55281 \\ ${ }^{2}$ Magister Sains Veteriner, Fakultas Kedokteran Hewan, Universitas Gadjah Mada, \\ Jl. Fauna 2 Karangmalang, Depok, Sleman, Yogyakarta 55281 \\ Yogyakarta \\ *Email: wahyuni_aeth@mail.ugm.ac.id; wahyuni_aeth@yahoo.com
}

Naskah diterima: 8 Agustus 2019, direvisi: 12 November 2019, disetujui: 30 November 2019

\begin{abstract}
With the prohibition of the use of Antibiotic growth promotors (AGP) used in animal feed, especially in broilers, the use of feed additives such as herbs, probiotics, prebiotics, synbiotics or mixtures of some of these ingredients is currently widely used as feed replacements for AGP substitutes. One of the commercial feed additives that contain combinations herbal and probiotics is Promi ${ }^{\circledR}$. In broiler maintenance, one vaccine that must be given is Newcastle Disease (ND) vaccine. The purpose of this study was to determine the role of supplementation of commercial feed combination of herbs and probiotics in broilers given ND vaccines. A total of 42 broilers were divided into two, group A (vaccinated with ND) and B (not vaccinated ND), each with 21 heads. Group A is divided into groups A1, A2 and A3 each with 7 heads. The A1 group is given only basal feed; A2 basal feed and AGP; A3 basal feed and Promix ${ }^{\circledR}$. Group B is divided by B1, B2 and B3 same as group A before. Broilers are maintained for 5 weeks and weighing each week. All data obtained were statistically analyzed using One Way ANOVA and continued with Duncan's post hoc test. The results of this study were that the group of chickens given the ND vaccine and given supplements of Promix ${ }^{\circledR}$ had greater weight gain $(P<0.05)$ compared to the AGP and basal groups in the fifth week while in the group of chickens that were not given the ND vaccine but given supplement Promix ${ }^{\circledR}$ feed had greater weight gain $(P<0.05)$ compared to the AGP and basal groups in the fourth week. In the fifth week there was no significant difference $(P<0.05)$ between all feed groups in the group not given the ND vaccine. The conclusion of this study that feed additives contain combinations herbal and probiotics can replace AGP as feed additive in broiler. By giving ND vaccine the weight gain of the feed group plus Promix ${ }^{\circledR}$ showed a significant increase in weight gain.
\end{abstract}

Key words: AGP; herbal; ND vaccines; probiotic; weight gain

\begin{abstract}
Abstrak
Dengan adanya pelarangan penggunaan Antibiotic growth promotors (AGP) yang digunakan dalam pakan ternak terutama pada broiler, maka penggunaan imbuhan pakan seperti herbal, probiotik, prebiotik, sinbiotik ataupun campuran antara beberapa bahan tersebut dewasa ini banyak digunakan sebagai imbuhan pakan pengganti AGP. Salah satu imbuhan pakan komersial yang mengandung kombinasi herbal dan probiotik adalah Promix $^{\circledR}$. Dalam pemeliharaan broiler, salah satu vaksin yang harus diberikan adalah vaksin Newcastle Disease (ND). Tujuan dari penelitian ini adalah untuk mengetahui peran imbuhan pakan komersial kombinasi herbal dan probiotik pada broiler yang diberikan vaksin ND. Sebanyak 42 ekor broiler dibagi menjadi dua yaitu kelompok A (dilakukan vaksinasi ND) dan B (tidak dilakukan vaksinasi ND) masing-masing 21 ekor. Kelompok A dibagi kelompok A1, A2 dan A3 masing-masing 7 ekor. Kelompok A1 diberi pakan basal saja; A2 pakan basal dan
\end{abstract}


AGP; A3 pakan basal dan Promix ${ }^{\circledR}$. Kelompok B dibagi B1, B2 dan B3 sama dengan kelompok A sebelumnya. Broiler dipelihara selama 5 minggu dan dilakukan penimbangan berat-badan setiap minggunya. Semua data yang diperoleh dianalisis secara statistik menggunakan One Way ANOVA dan dilanjutkan dengan uji post hoc Duncan. Hasil dari penelitian ini adalah bahwa kelompok ayam yang diberi vaksin ND dan diberi imbuhan pakan Promix ${ }^{\circledR}$ memiliki pertambahan berat badan yang lebih besar $(P<0.05)$ dibandingkan dengan kelompok AGP maupun basal pada minggu kelima sedangkan pada kelompok ayam yang tidak diberi vaksin ND namun diberi imbuhan pakan Promix ${ }^{\circledR}$ memiliki pertambahan berat badan yang lebih besar $(P<0.05)$ dibandingkan dengan kelompok AGP maupun basal pada minggu keempat. Pada minggu kelima tidak ada perbedaan signifikan $(P<0.05)$ antara semua kelompok pakan pada kelompok yang tidak diberi vaksin ND. Kesimpulan dari penelitian ini adalah bahwa imbuhan pakan kombinasi herbal dan probiotik dapat menggantikan AGP sebagai imbuhan pakan pada broiler. Dengan pemberian vaksin ND pertambahan berat badan kelompok pakan yang ditambah Promix ${ }^{\circledR}$ menunjukkan peningkatan pertambahan berat badan yang signifikan.

Kata kunci : AGP; herbal; pertambahan berat badan; probiotik; vaksin ND

\section{Pendahuluan}

Imbuhan pakan adalah bahan yang dicampur dalam pakan ternak yang dapat memengaruhi kesehatan, produktivitas, dan kondisi gizi hewan ternak. Imbuhan pakan sudah umum digunakan dalam industri perunggasan yaitu antibiotik dimana paling luas penggunaannya di seluruh dunia. Penggunaan antibiotik sebagain pemacu pertumbuhan atau yang biasa disebut dengan istilah antibiotic growth promotor (AGP) memiliki dampak negatif seperti residu dalam jaringan, resistensi antimikroba dan resistensi silang dalam terapi antimikroba (Mehdi et al., 2018). Oleh karena itu, di Indonesia melalui Peraturan Menteri Pertanian Republik Indonesia Nomor 14/ PERMENTAN/PK.350/5/2017 secara resmi telah melarang penggunaan AGP untuk imbuhan pakan ternak yang produknya dikonsumsi manusia.

Adanya pelarangan penggunaan AGP sebagai imbuhan pakan pada ternak menyebabkan peralihan penggunaan imbuhan pakan lain selain antibiotik seperti probiotik, prebiotik, sinbiotik, herbal dan beberapa jenis enzim baik dalam bentuk tunggal maupun gabungan antara beberapa jenis imbuhan pakan tersebut. Promix ${ }^{\circledR}$ merupakan salah satu jenis imbuhan pakan komersial yang merupakan campuran antara probiotik dan herbal. Probiotik merupakan mikroorganisme hidup yang bila diberikan dalam jumlah yang cukup memberikan manfaat kesehatan pada host (Mousavi et al. 2018). Pemberian probiotik pada broiler dapat meningkatkan pertambahan berat badan, memperbaiki FCR dan meningkatkan kecernaan makanan (Bai et al., 2012; Nikpiran et al., 2013). Penggunaan herbal seperti jahe (Zingiber officinale) pada broiler dapat memberikan efek positif pada performa broiler (Mohamed et al., 2012).
Penelitian secara in vitro menggunakan kombinasi probiotik dan herbal yang dilakukan oleh Prakasita et al. (2019) menunjukan bahwa beberapa jenis herbal dapat mendukung pertumbuhan dari probiotik.

Newcastle Disease (ND) merupakan suatu penyakit pernapasan dan sistemik, yang bersifat akut dan mudah sekali menular, yang disebabkan oleh virus dan menyerang berbagai jenis unggas terutama ayam. Di Indonesia, ND dapat ditemukan pada peternakan broiler dan layer maupun ayam kampung (buras) di berbagai daerah di seluruh penjuru tanah air, terutama daerah yang padat peternakan ayam (Tabbu, 2000). Oleh karena itu, dalam pemeliharaan broiler tindakan pencegahan seperti program vaksinasi menggunakan vaksin ND sangatlah penting terutama untuk menghasilkan titer antibodi yang bersifat protektif agar bisa mencegah infeksi virus ND.

Penelitian mengenai pemanfaatan imbuhan pakan komersial Promix ${ }^{\circledR}$ sebagai alternaif pengganti AGP pada broiler yang kemudian diberikan vaksin ND belum pernah dilakukan. Penelitian ini bertujuan untuk mengetahui peran Promix ${ }^{\circledR}$ sebagai alternatif pengganti AGP pada broiler yang diberi vaksin ND.

\section{Materi dan Metode}

Hewan percobaan yang dipakai dalam penelitian ini adalah broiler strain cobb sebanyak 42 ekor. Kandang ayam dengan semua fasilitas pemeliharaan disiapkan dan didesinfeksi. Day old chicken (DOC) broiler tersebut dibagi menjadi dua yaitu kelompok A (dilakukan vaksinasi ND) dan B (tidak dilakukan vaksinasi ND) masing-masing 21 ekor. Kelompok A dibagi kelompok A1, A2 dan A3 masing-masing 7 ekor. Kelompok A1 diberi pakan basal saja; A2 pakan basal dan AGP; A3 pakan basal dan Promix ${ }^{\circledR}$. Kelompok 
$\mathrm{B}$ dibagi $\mathrm{B} 1, \mathrm{~B} 2$ dan $\mathrm{B} 3$ sama dengan kelompok $\mathrm{A}$ sebelumnya.

Pemeliharaan dilakukan selama 5 minggu. Pemberian imbuhan pakan pada broiler dilakukan dari awal pemeliharaan sampai akhir pemeliharaan. Pencampuran pakan basal dengan AGP dan Promix ${ }^{\circledR}$ dilakukan secara manual sesuai dengan dosis anjuran yang tertera pada bungkusan produk. Air minum yang digunakan adalah air mineral RO (air mineral yang dibuat menggunakan teknologi Reverse Osmosis). Selama penelitian pemberian pakan dan air minum dilakukan secara ad libitum.

Komposisi detail dari pakan basal seperti formulasi dasar yang direkomendasikan oleh Cobb Broiler Management Guide. Imbuhan pakan komersial Promix ${ }^{\circledR}$ mengandung probiotik (Bacillus subtilis, Biffidobacterium bifidum, Biffidobacterium longum, Lactobacillus acidophilus, Saccharomyces cerevisiae) dan herbal (Zingiber offocinale, Curcuma xanthorriza, Curcuma aeruginosa, Curcuma domestica, Kaempferia galanga). Antibiotic growth promotor (AGP) yang digunakan adalah enramicyn.

Pemberian vaksinasi ND dilakukan sebanyak 2 kali yaitu vaksinasi dengan vaksin gabungan Newcastle disease-infectious bronchitis (ND-IB) live tetes mata pada hari ke-7 dan pemberian vaksin ulangan (booster) diberikan pada umur ke-18 hari menggunakan vaksin ND killed melalui injeksi subkutan. Penimbangan berat badan dilakukan setiap minggu selama pemeliharaan dan kemudian dilakukan perhitungan pertambahan berat badan. Data pertambahan berat badan masing-masing ayam pada setiap keompok kemudian dirata-ratakan sehingga diperoleh ratarata pertambahan berat badan setiap kelompok.

Hasil perhitungan pertambahan berat badan setiap minggu dari masing-masing kelompok kemudian dilakukan uji normalitas dan homogenitas yang selanjutnya dilanjutkan dengan uji One Way ANOVA pada program SPSS 24. Hasil uji One Way ANOVA yang menunjukan ada perbedaan yang signifikan kemudian dilanjutkan dengan uji Post Hoc Duncan.

\section{Hasil dan Pembahasan}

Peran kombinasi herbal-probiotik pada imbuhan pakan komersial Promix ${ }^{\circledR}$ terhadap pertambahan berat badan broiler selama 5 minggu pemeliharaan baik dari kelompok yang diberi vaksin ND maupun kelompok yang tidak diberi vaksin ND dapat dilihat pada Tabel 1 dan Tabel 2.

Berdasarkan data pada Tabel 1. pada kelompok yang diberi vaksin ND dapat dilihat bahwa pertambahan berat badan dari minggu pertama sampai minggu ketiga dari masing-masing kelompok pakan tidak terdapat perbedaan yang signifikan $(P<0.05)$. Sedangkan pada minggu keempat dan kelima pertambahan berat badan dari masing-masing kelompok pakan terlihat adanya perbedaan yang signifikan. Pada minggu keempat kelompok yang diberi imbuhan pakan Promix ${ }^{\circledR}$ memiliki pertambahan berat badan yang terendah jika dibandingkan dengan kelompok yang

Tabel 1. Pertambahan berat badan broiler kelompok yang divaksin ND selama 5 minggu pemeliharaan

\begin{tabular}{lllllc}
\hline \multirow{2}{*}{ Kelompok Pakan } & \multicolumn{5}{c}{ Pertambahan Berat Badan (g) } \\
\cline { 2 - 6 } & Minggu 1 & Minggu 2 & Minggu 3 & Minggu 4 & Minggu 5 \\
\hline Basal & $87.66^{\mathrm{a}}$ & $285.66^{\mathrm{a}}$ & $445.4^{\mathrm{a}}$ & $485.6^{\mathrm{a}}$ & $509^{\mathrm{a}}$ \\
Basal+AGP & $90.5^{\mathrm{a}}$ & $297.16^{\mathrm{a}}$ & $446.16^{\mathrm{a}}$ & $488.16^{\mathrm{a}}$ & $548.16^{\mathrm{a}}$ \\
Basal+Promix ${ }^{\mathrm{a}}$ & $93.33^{\mathrm{a}}$ & $327.33^{\mathrm{a}}$ & $452.66^{\mathrm{a}}$ & $275.16^{\mathrm{b}}$ & $829.8^{\mathrm{b}}$ \\
\hline
\end{tabular}

ab Superskrip yang berbeda pada setiap baris menunjukan perbedaan yang signifikan $(P<0.05)$

Tabel 2. Pertambahan berat badan broiler kelompok yang tidak diberi divaksin ND selama 5 minggu pemeliharaan

\begin{tabular}{lccccc}
\hline Kelompok Pakan & \multicolumn{5}{c}{ Pertambahan Berat Badan (g) } \\
\cline { 2 - 6 } & Minggu 1 & Minggu 2 & Minggu 3 & Minggu 4 & Minggu 5 \\
\hline Basal & $97.2^{\mathrm{a}}$ & $310.8^{\mathrm{a}}$ & $460.6^{\mathrm{a}}$ & $335.8^{\mathrm{a}}$ & $585.4^{\mathrm{a}}$ \\
Basal+AGP & $114.5^{\mathrm{a}}$ & $350.83^{\mathrm{a}}$ & $458.3^{\mathrm{a}}$ & $430.6^{\mathrm{ab}}$ & $549.6^{\mathrm{a}}$ \\
Basal+Promix ${ }^{\mathrm{a}}$ & $94.66^{\mathrm{a}}$ & $307.6^{\mathrm{a}}$ & $466.6^{\mathrm{a}}$ & $484.6^{\mathrm{b}}$ & $500.8^{\mathrm{a}}$ \\
\hline
\end{tabular}

ab Superskrip yang berbeda pada setiap baris menunjukan perbedaan yang signifikan $(P<0.05)$ 
diberi pakan basal maupun imbuhan AGP, namun pada minggu kelima terjadi peningkatan secara signifikan pada kelompok yang diberi pakan Promix ${ }^{\circledR}$ dimana memiliki pertambahan berat badan yang terbesar jika dibandingkan dengan kelompok pakan basal atau imbuhan AGP.

Pada Tabel 2. kelompok yang tidak diberi vaksin ND dari minggu pertama sampai minggu ketiga dan pada minggu kelima tidak terdapat perbedaan yang signifikan $(P<0.05)$ antara masing-masing kelompok pakan, namun pada minggu keempat terdapat perbedaan yang signifikan dimana pertambahan berat badan kelompok yang diberi imbuhan Promix $^{\circledR}$ memiliki pertambahan berat badan lebih besar dibandingkan dengan kelompok pakan yang diberi pakan basal dan dan imbuhan AGP.

Hasil studi ini sejalan dengan penelitian yang dilakukan oleh Yadav et al. (2018) dimana pemberian probiotik Bacillus subtilis dapat meningkatkan berat badan secara signifikan dibandingkan dengan kelompok kontrol. Penelitian yang dilakukan oleh Peric et al. (2010) juga mengungkapkan bahwa pemberian probiotik (Lactobacillus reuteri, Enterococcus faecium, Bifidobacterium animalis, Pediococcus acidilactici dan Lactobacillus salivarius) secara signifikan dapat meingkatkan berat badan. Lebih lanjut penelitian yang dilakukan oleh Silva et al. (2011) juga menyatakan bahwa pemberian probiotik (Lactobacillus acidophilus, Streptococcus faecium, Bifidobacterium bifidum) memiliki pertambahan berat badan yang lebih besar dibandingkan dengan pemberian antibiotik (flavomycin, halquinol). Penelitian menggunakan herbal (Zingiber offocinale) pada pakan broiler juga dapat meningkatkan palatabilitas dan kecernaan sehingga dapat meningkatkan berat badan (Zang et al., 2009; Herawati, 2010; Mohamed et al., 2012; Kafi et al., 2017)

Kombinasi probiotik dan herbal yang terkandung di dalam imbuhan pakan Promix ${ }^{\circledR}$ memiliki efek sinergistik. Efek sinergistik ini digambarkan dari hasil penelitian yang diperoleh dimana pemberian Promix ${ }^{\circledR}$ dapat menigkatkan pertambahan berat badan. Hal ini didukung oleh penelitian secara in vitro yang dilakukan oleh Prakasita et al. (2019) yang membuktikan bahwa bakteri probiotik Lactobacillus acidophilus dan $L$. brevis didukung pertumbuhannya pada media yang mengandung ekstrak temulawak, jahe merah dan kunyit.
Pemberian vaksin ND merupakan program rutin yang dilakukan pada tingkat peternakan. Probiotik dan herbal memiliki efek imunomudulator sehingga dapat meningkatkan titer antibodi terhadap ND. Beberapa penelitian sebelumnya yang menggunakan herbal (Curcuma longa) (Zaki et al., 2016) dan probiotik (Lactobacillus , Streptococcus dan Bifidobacterium) (Talazadeh et al., 2016) dapat meningkatkan titer antibodi HI terhadap ND. Efek imunomudulator yang dimiliki oleh probiotik dan herbal ini kemungkinan menyebabkan kelompok yang diberi imbuhan pakan Promi $x^{\circledR}$ memiliki status imun yang baik sehingga dapat mendukung tercapainya performa yang maksimal.

\section{Kesimpulan}

Imbuhan pakan komersial Promix ${ }^{\circledR}$ dapat menggantikan AGP sebagai imbuhan pakan pada broiler dimana Promix ${ }^{\circledR}$ dapat meningkatkan pertambahan berat badan yang lebih besar dibandingkan dengan kelompok pakan basal dan AGP. Dengan pemberian vaksin ND pertambahan berat badan meningkat secara signifikan sampai minggu kelima pemeliharaan.

\section{Ucapan Terima Kasih}

Terima kasih kepada Fakultas Kedokteran Hewan, Universitas Gadjah Mada yang telah memberikan Dana Hibah Penelitian Kompetitif Fakultas tahun 2018, sehingga penelitian ini dapat terlaksana dengan baik.

\section{Daftar Pustaka}

Bai, S.P., Wu, A.M., Ding, X.M., Lei, Y., Bai, J., Zhang, K.Y. and Chio, J.S. (2012). Effects of probioticsupplemented diets on growth performance and intestinal immune characteristics of broiler chickens. Poult. Sci. 92: 663-670.

Herawati. (2010). The Effect of feeding red ginger as phytobiotic on body weight gain, feed conversion and internal organs condition or broiler. Int. J. Poult. Sci. 9: 963-967.

Kafi, A., Uddin, M.N., Uddin, M.J., Khan, M.M.H.and Haque, M.E. (2017). Effect of Dietary Supplementation of Turmeric (Curcuma longa), Ginger (Zingiber officinale) and their Combination as Feed Additives on Feed Intake, Growth Performance and Economics of Broiler. Int. J. Poult. Sci. 16(7): 257-265. 
Mehdi, Y., Letourneau-Montminy, M.P., Gaucher, M.L., Chorfi, Y., Suresh, G., Rouissi, T., Brar, S.K., Cote, C., Ramirez, A.A. and Godbout, S. (2018). Use of antibiotics in broiler production: Global impacts and alternatives. Anim. Nutr. 4: 170-178.

Mohamed, A.B., Mohammed, A.M., Al-Rubaee and Jalil, A.Q. (2012). Effect of Ginger (Zingiber officinale) on Performance and Blood Serum Parameters of Broiler. Int. J. Poult. Sci. 11(2): 143-146.

Mousavi, S.M.A.A., Hosseini, H.M. and Mirhosseini, S.A. (2018). A Rview of Dietary Probiotics in Poultry. J. Appl. Biotechnol. Rep. 5(2): 48-54.

Nikpiran, H., Taghavi, M., Khodadadi, A. and Athari, S.S. (2013). Influence of Probiotic and Prebiotic on broiler chickens performance and immune status. Journal of Novel Applied Sciences. 2(8):256-259.

Perić, L., Milošević, N., Žikić, D., Bjedov, S., Cvetković, D., Markov, S., Mohnl, M. and Steiner, T. (2010). Effects of probiotic and phytogenic products on performance, gut morphology and cecal microflora of broiler chickens. Archiv Tierzucht. 53(3): 350-359.

Prakasita, V.C., Asmara, W., Widyarini, S and Wahyuni, A.E.T.H. (2019). Combination of herbs and probiotics as an alternative growth promoter: An in vitro study. Vet. World. 12(4): 614-620.
Silva, W.T.M., Nunes, R.V. and Pozza, P.C. (2011). Evaluation of inulin and probiotic for broiler chickens. Acta Scientiarum Animal Sciences. 33(1): 19-24.

Tabbu, C.R. (2000). Penyakit Ayam dan Penanggulangannya Volume 1. Kanisius. Yogyakarta: 164-186.

Talazadeh, F., Mayahi, M. and Zeinali, S. 2016. The effect of Aquablend Avian probiotic ${ }^{\circledR}$ including Lactobacillus, Streptococcus and Bifidobacterium on systemic antibody response against Newcastle and Influenza disease vaccine in broiler chickens. Int. J. Enteric. Pathog. 4(2):e35689.

Yadav, M., Dubey, M., Yadav, M. and Shankar, K.S. 2018. Effect of Supplementation of Probiotic (Bacillus subtilis) on Growth Performance and Carcass Traits of Broiler Chickens. Int. J. Curr. Microbiol. App. Sci. 7: 4840-4849.

Zaki, M.M., El-Ghany, W.A.A., Hady, M.M. and Korany, R.M.S. (2016). Effect of Certain Phytobiotics on the Immune Response of Newcastle Disease Vaccinated Broiler Chickens. Asian J. Poult. Sci. 10: 134-140.

Zang, G.F., Yang, Z.B., Wang, Y., Yang, W.R., Jiang, S.Z. and Gai, G.S. (2009). Effect of ginger root (Zingiber officinale) processed to different particle size on growth performance, antioxidant status and serum metabolites of broiler chickens. Poult. Sci. 88: 2159-2166. 